\title{
Pollution Risks Accompanied with Economic Integration of ASEAN Countries and the Fragmentation of Production Processes
}

\author{
Tetsuo Kida ${ }^{1} \&$ Ryo Fujikura ${ }^{2}$ \\ ${ }^{1}$ Graduate School of Public Policy and Social Governance, Hosei University, Tokyo, Japan \\ ${ }^{2}$ Faculty of Humanity and Environment, Hosei University, Tokyo, Japan. \\ Correspondence: Mr. Tetsuo Kida, Graduate School of Public Policy and Social Governance, Hosei University, \\ Chiyodaku, Tokyo, 102-8160 Japan.
}

Received: June 29, 2015

doi:10.11114/ijsss.v3i5.915
Accepted: July 15, 2015

Available online: July 22, 2015

URL: http://dx.doi.org/10.11114/ijsss.v3i5.915

\begin{abstract}
Economic integration in the Southeast Asian region has been rapidly progressing resulting in an accelerating fragmentation of the production processes. Thai multinational corporations have moved factories over their national borders. Similar fragmentation arose along the US-Mexico border from the 1970s and resulted in serious industrial pollution in Mexico along the national border. This paper examines the risks of pollution accompanied with the fragmentation of the production processes. The current state of industrial areas in Cambodia and Myanmar, along the national border of Thailand, is analyzed in relation to Maquiladoras in Mexico and industrial areas in India. An international environmental agreement, similar to what was agreed upon between Mexico and the US, would seem to be the most effective way to prevent pollution.
\end{abstract}

Keywords: pollution, Maquiladora, economic integration, fragmentation, ASEAN, AFTA

\section{Introduction}

Member countries of the Association of Southeast Asian Nations (ASEAN) have been integrating their economic activities. The establishment of the ASEAN Economic Community (AEC) ${ }^{1}$ was planned for 2015, as was the elimination of all tariffs for the ASEAN Free Trade Area (AFTA). Multinational corporations (MNCs) have pursued increased productivity by establishing production facilities throughout the region and improving logistics. Factories producing raw materials, primary parts, secondary products and final products are being established in different countries through trans-boundary investment. A common practice has become to produce parts in Cambodia, Laos or Myanmar and to create final products in Thailand. Large production networks have been established in the region and the production processes are becoming fragmented (Ishikawa, 2013).

Similar trans-boundary investments were accelerated by the Maquila system enacted in 1965 along the US border in Mexico. Factories designated as Maquiladoras were established in the east and performed simple labors. Then, they moved to the western areas as the economy developed, and factories using high technology to produce such things as electronic components were established. The factories caused significant environmental pollution due to the creation of hazardous waste as the byproduct of auxiliary inputs in the industrial processes (Sanchez, 1990). The environmental damage was unchecked as there was a lack of proper implementation of Mexican environmental laws and regulations during the 1990s (Perry, Sanchez, Glaze \& Mazari, 1990). In order to deal with these problems, the governments of the United States and Mexico formed the North American Agreement on Environmental Cooperation (NAAEC), and after later economic integration, the North American Free Trade Agreement (NAFTA). These steps worked to ensure the enforcement of domestic environmental laws in the United States and Mexico, and as a result, succeeded in a reduction of environmental pollution (Kin, 1999).

A situation similar to what could be observed in Mexico before NAFTA, in terms of insufficient pollution control, now exists in the ASEAN region. While environmental laws and regulations have been established and enforced to some

1 At the Bali Summit in October 2003, ASEAN leaders declared that AEC shall be the goal of the regional economic integration (Bali Concord II ) by 2020. Then, they decided to accelerate the establishment of the ASEAN Community, including its AEC pillar by 2015 at the $12^{\text {th }}$ ASEAN Summit in Cebu, the Philippines, on 13 January 2007 (ASEAN, 2008). 
degree in Thailand, both Cambodia and Myanmar are largely lacking. We are concerned that a similar pattern of events, just as caused the spike in pollution which existed in Mexico in the 1990's, will develop as both the economic integration of the ASEAN region and fragmentation of MNCs production processes increases.

In this paper, we first give an overview of the economic integration of ASEAN and fragmentations of MNCs' production processes. We then analyze the intersection of Maquiladoras in Mexico and NAFTA, and the present situation of pollution control in India as precedent cases of industrial areas established by FDI. A comparison of environmental laws and their enforcement in Thailand, Cambodia and Myanmar is given. Finally, we evaluate the potential environmental impact of the economic integration in the ASEAN region and propose a possible measure.

\section{AEC}

ASEAN (2008) planned for the AEC to be established in order to integrate the ASEAN countries as a single market and production base, making the entire region more dynamic and competitive with new mechanisms and measures to strengthen the implementation of its existing economic initiatives (ASEAN 2008). As a first step towards completing the AEC, ASEAN will establish AFTA in 2015. However, the economic situations of member countries in AFTA (the population of which is over 600 million) are far more diverse when compared to other free trade area such as NAFTA or the EU. AFTA ranges from the economically-developed Singapore to their least-developed country, Cambodia. Furthermore, both the economic and environmental impacts of the integration of ASEAN countries are anticipated to be more significant than previous similar examples.

To realize AEC, ASEAN adopted the ASEAN Economic Community Blueprint in 2008. It clarifies goals and a schedule of actions, presenting 4 "Strategic Approaches" and 15 "Core Elements" (Table 1). The performance of each member country is evaluated by "AEC Scorecards". The comprehensive percentage of achievement according to the AEC Scorecard from 2008 to 2011 was $67.5 \%$ (Shimizu, 2013). It should be noted that environmental policy is not included in the Blueprint at all'2.

Table 1. ASEAN Economic Community Blueprint

$$
\text { Strategic Approach }
$$

Core Elements

\begin{tabular}{ll}
\hline A. Towards a Single Market and Production Base & A1. Free Flows of Goods \\
& A2. Free Flow of Services \\
A3. Free Flows of Investment \\
& A4. Free Flow of Capital \\
& A5. Free Flows of Skilled Labor \\
& A6. Priority Integration Sector \\
& A7. Food, Agriculture and Forestry \\
\hline B. Towards a High Competitive Economic Region & B1. Competitive Policy \\
& B3. Intellectual Property Rights \\
& B4. Infrastructure Development \\
& B5. Taxation \\
& B6. E-Commerce \\
\hline C. Towards a Region of Equitable Economic Development & C1. SME Development \\
& C2. Initiative for ASEAN Integration (IAI) \\
\hline D. Towards Full Integration into the Global Economy & D1. Coherent Approach Towards External \\
& Economic Relations and Enhanced \\
& Participation in Global Supply Networks
\end{tabular}

(Source) Association of Southeast Asian Nations [ASEAN] (2008)

\section{Fragmentation of Production Processes}

When Japanese companies established their international production networks some decades ago, they located their head office and mother factories in Japan, producing intermediate materials by skilled laborers in Japan. Then, the intermediate materials were sent to Thailand to be assembled by unskilled local laborers, and the final products were sent back to Japan or exported to other countries. As Thailand became a semi-developed country, and developed the ability to produce intermediate materials by skilled local laborers, some Japanese MNCs shifted their mother factories from Japan to Thailand. They started to produce intermediate materials in Thailand, and to have final product assembly done by unskilled laborers in Cambodia, Laos or Myanmar (Figure 1). In 2014, Thailand enacted their Minimum Wage Policy. This policy increased labor costs in Thailand, and further facilitated the fragmentation of production processes to

2 ASEAN Socio-Cultural Community Blueprint details Ensuring Environmental Sustainability, which focuses on Transboundary Haze Pollution and Transboundary Movement of Hazardous Wastes (ASEAN, 2009). 
neighboring countries (Kida \& Fujikura, 2015).

Tax exemption and reduction for MNCs by ASEAN countries further stimulated the fragmentation (Kasuga, 2014). Moreover, the rehabilitation of infrastructure in the area facilitated trans-boundary transportation. The East-West Economic Corridor (EWEC) is 1,450 kilometers long and internationally connects Mawlamyaing in Myanmar and Da Nang in Vietnam. It was rehabilitated through a collaboration between the Thai, Vietnamese and Lao governments. Myanmar recently joined the rehabilitation project and has opened to immigration for foreigners. The Southern Economic Corridor (SEC) has been developed by Thailand, Cambodia and Vietnam, connecting Bangkok in Thailand and Ho Chi Minh in Vietnam. These trans-boundary investments by MNCs have driven job creation and economic revitalization in neighboring areas, as well as the immediate area.

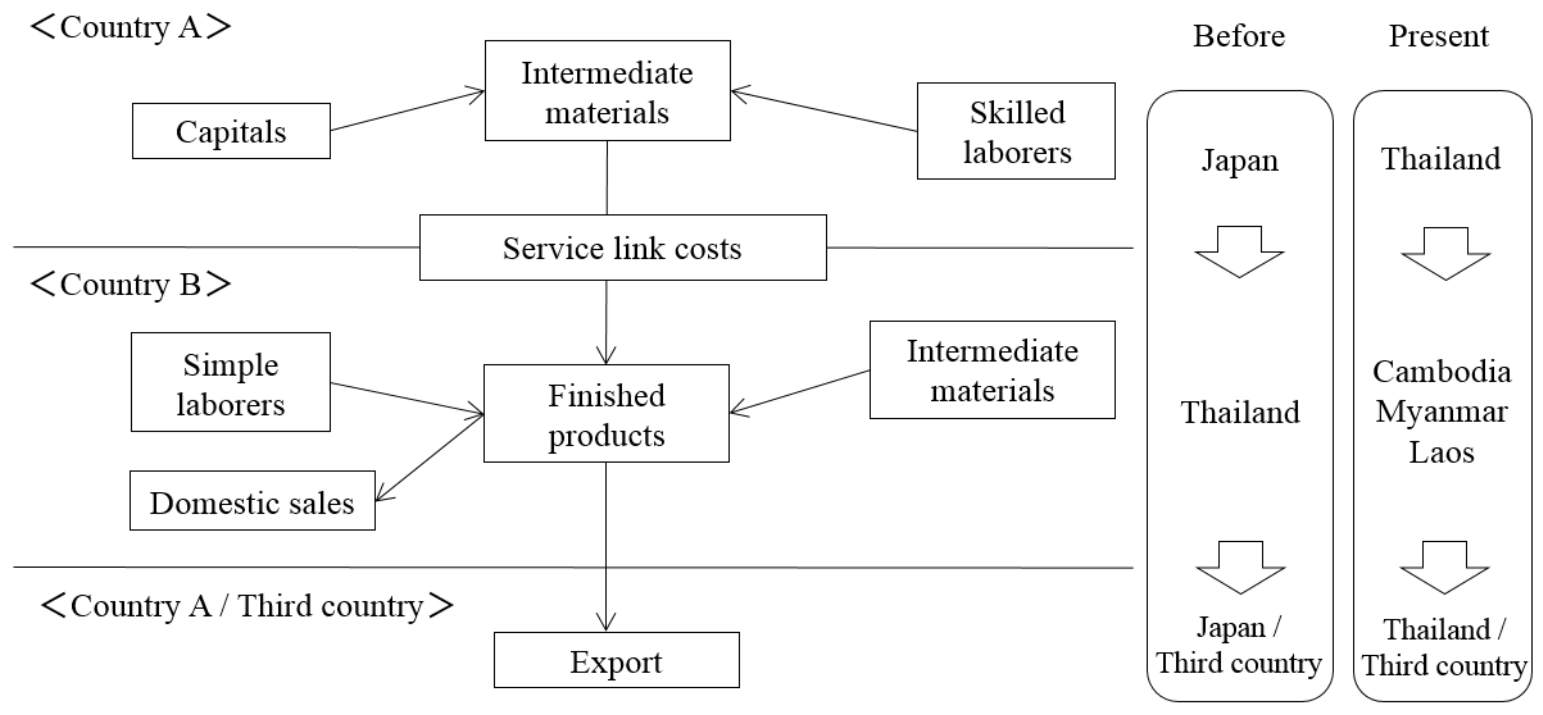

Figure 1. Fragmentation of the production processes in ASEAN

(Source) Prepared by authors from Ishido \& Ito, (2014)

\section{Environmental pollution in Maquiladoras and NAFTA}

The Maquila system in Mexico was enacted in 1965 in order to reduce the number of Mexican illegal residents in the US, mostly landless farmers at home. The Maquila system designated factories located in Mexico as "Maquiladora." They were exempted of taxation on the raw materials, parts and production equipment needed to produce export products. Maquiladoras were built by American MNCs, and were located along the U.S. border. It was expected that the Maquiladoras would absorb illegal unskilled workers back from the US. In fact, the Maquila system successfully contributed to the industrialization of Mexico, contributing FDIs, job creation, the acquisition of foreign currency and the obtaining of skills and techniques. It later contributed to Mexico's national import substitution policy (Taniura, 2000).

As the Mexican economy developed and matured enough to be able to supply sophisticated infrastructures and skilled workers, the Mexican government adopted the National Development Plan to promote high technology industry. By 1990, new agglomerations of high technology industries were developed near the border of northwestern Mexico: Tijuana, Tecate, Mexicali, Nogales and Agua Prieta etc. (Sanchez, 1990). Some Maquiladoras of heavy industries generated large amounts of hazardous waste and their illegal dumping caused serious pollution (Perry, Sanchez, Glaze \& Mazari, 1990, Bowen, Kontuly \& Henpner, 1995, Rajaram \& Das, 2008). ${ }^{3}$

When Mexico negotiated to join the North American Free Trade Agreement (NAFTA), there were concerns expressed that pollution along the Mexican border had become more serious as investment from the US had increased. As a measure to control environmental problems, the US, Canada and Mexico created the North American Agreement on Environmental Cooperation (NAAEC) to complement NAFTA (Gallagher, 2004). The agreement successfully

3 For example, Maquiladoras at Mexicali industrial area in 1990s, 1) they were mostly U.S. subsidiaries, 2) they were imported from the U.S. (98\%), 3) hazardous materials were a wide range of solvents (alcohols, freons, cetons, and aromatic hydrocarbons), acid and alkaline substances, and heavy metals, 4) most hazardous materials were auxiliary inputs to the manufacturing process (Sanchez, 1990). 
contributed to the control of pollution problems (Kin, 1999). To put it another way, the economic integration of Mexico by NAFTA facilitated environmental management in Mexico.

\section{India}

\subsection{Pollution Control at Industrial Areas}

India has had established environmental laws since as early as the 1970 s. $^{4}$ However, they are weakly enforced and pollution is still created. Citizens have spoken out against pollution, but both the central and local government have seldom taken effective measures. If an area has an active judge, he or she has prevailingly taken action against an offending factory. However, this depends on the judge's personal interest, and no regional or national action has taken place (Tsujita, 2005).

We conducted interviews with administrators of industrial areas in six states of India: Haryana state (Bawal Industrial Area), Rajasthan state (Neemurana Industrial Area), Uttar Pradesh state (Greater Noida Industrial Area), Andhra Pradesh state (Sri City Industrial Area), Tamil Nadu state (Mahindra Industrial Area) and Gujarat state (Hazira Industrial Area). The interviews revealed that all industrial areas can supply water. Most industrial areas installed water supply facilities or allow the factories to draw up underground water. However, some industrial areas have not installed wastewater treatment facilities or hazardous waste management facilities despite the requirement of installing these facilities. There are regulations made by the government, but there are no penalties for violating the regulations (Table 2).

Table 2. Environmental measures at industrial areas in India

\begin{tabular}{|c|c|c|c|c|c|c|}
\hline Industrial Area & Bawal & Neemurana & Greater Noida & Sri City & Mahindta & Hajira \\
\hline State & Haryan & Rajasthan & Uttar Pradesh & Andhra Pradesh & Tamil Nadu & Gujara \\
\hline Developper & HSIIDC & RIICO & GNIDA & Sri City & Mahindra Group & GIDC \\
\hline \multicolumn{7}{|l|}{ Water Supply } \\
\hline Water Supply Facility & $\mathrm{O}$ & $\mathrm{O}$ & & $\mathrm{O}$ & $\mathrm{O}$ & $\mathrm{O}$ \\
\hline Underground water & & $\mathrm{O}$ & $\mathrm{O}$ & & $\mathrm{O}$ & \\
\hline Regulations & $\mathrm{O}$ & $\mathrm{O}$ & $\mathrm{O}$ & $\mathrm{O}$ & $\mathrm{O}$ & $\mathrm{O}$ \\
\hline \multicolumn{7}{|l|}{ Waste Water Treatment } \\
\hline Waste Water Treatment Facility & $\mathrm{O}$ & & & & $\mathrm{O}$ & $\mathrm{O}$ \\
\hline \multicolumn{7}{|l|}{ Dumping at site } \\
\hline Regulations & $\mathrm{O}$ & $\mathrm{O}$ & & & & \\
\hline \multicolumn{7}{|l|}{ Hazardous Waste } \\
\hline Waste Management Facility & & & & & $\mathrm{O}$ & \\
\hline Dumping at site & & & & $\mathrm{O}$ & $\mathrm{O}$ & \\
\hline \multicolumn{7}{|l|}{ Intermidiate Treatment Facility } \\
\hline \multicolumn{7}{|l|}{ Final Disposal Area } \\
\hline Regulations & & & & & & \\
\hline
\end{tabular}

(Source) Prepared by authors

\subsection{A Japanese factory in India}

We conducted interviews with a Japanese factory located in the Greater Noida Industrial Area. This industrial area has neither a wastewater treatment nor a waste management central processing facility, so all factories are required to treat their waste within their own properties. This factory is a chemical plant, and it mainly uses water for the manufacturing process, the canteen (cafeteria) and the toilets.

Water is used for different purposes at the factory and is given different treatment afterwards depending on the usage. First, the water used in machines for cooling purpose is taken from an underground water tank. Over the course of regular use it becomes dirty, and is sent to an STP (Sewerage Treatment Plant) system for treatment. The water from the canteen contains oil particles, hence the water is sent to a grease trap to separate the oil particles from water. This oil-free water is then sent to an STP system for treatment. The water from the toilet is sent directly to an STP system for

4 The Water (Protection and Control of Pollution) Act was enacted in 1974, and The Water (Protection and Control of Pollution) Cess Act was enacted in 1977. 
treatment.

The water in an STP system is treated in two ways:

1) Mechanical: In this process, pumps inside the system send the water into carbon filters that rotate the water. Then, the process of air purging is used to agitate the water.

2) Organic: In this process, bacteria are induced into the water to remove solid waste. To ensure that bacteria are present, oxygen is used. Then the liquid form of the waste is treated with chemicals.

The treated water is used for gardening. As per government regulations, the responsibility to treat waste water is on the organization working at the site (Figure 2).

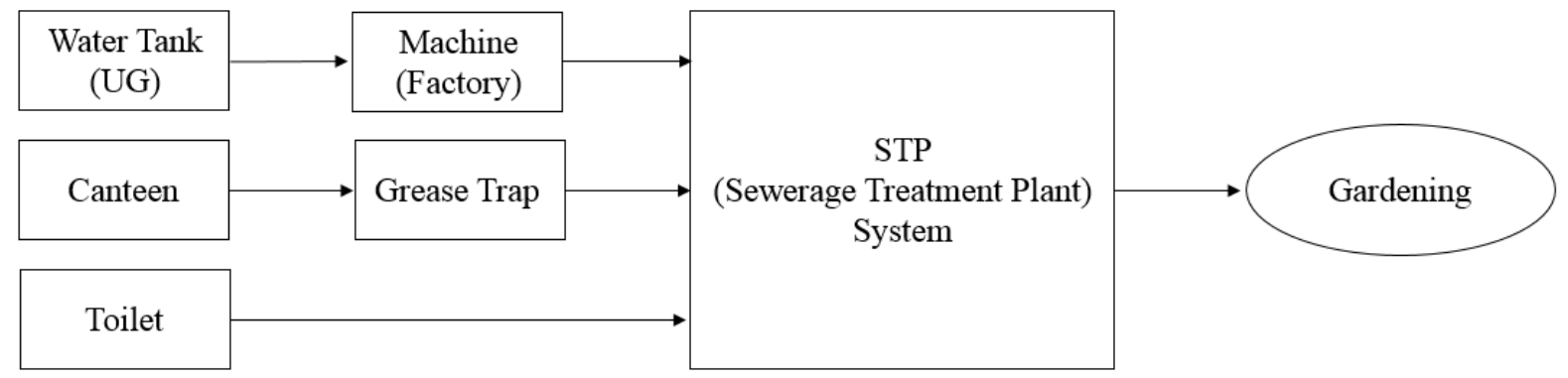

Figure 2. Waste water treatment system at a Japanese factory in India

(Source) Prepared by authors

Other types of waste created during the production process include resin bags, empty solvent drums, and dirty rags used for cleaning purposes. This waste is sent to scrap dealers who are authorized by the government.

They deal with the waste in two ways:

1) Reuse: The scrap dealer cleans the waste and passes it on for further use.

2) Recycle: The scrap dealer sends the waste to private recycling plants who are authorized by the government to clean and recycle it for further use. These plants are present at areas such as the Merrut district (Haryana state) and the Panipat district (Uttar Pradesh state) etc.

As per the government regulations, separate "storage yards" need to be built at the site for the storage of waste before it is sent to a scrap dealer. Furthermore, the responsibility to treat hazardous waste is on the organization working at the site (Figure 3).

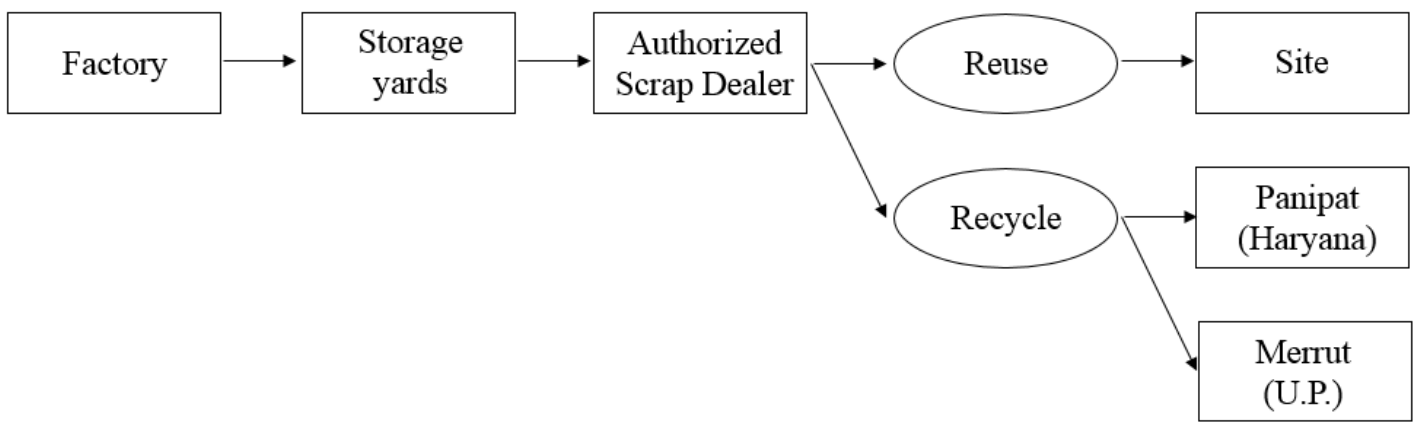

Figure 3. Hazardous waste treatment system at a Japanese factory in India

(Source) Prepared by authors

Japanese factories installed both wastewater treatment facilities and hazardous waste management systems within their own sites. They are highly conscious of the environment, and that compensates for the lack of enforcement of laws in India. In other words, whether pollution from the industrial areas is properly controlled depends on the compliance readiness of the individual companies, where the environmental laws are poorly implemented. It may be too optimistic to expect that pollution will be controlled in the future as more foreign companies move into the areas.

\section{Thailand}

Thailand enacted the Enhancement and Conservation of National Environmental Quality Act in 1975. Accordingly, the 
government established a department to deal with environmental issues: the National Environment Board. However, environmental pollution in industrial areas was exclusively handled by the Department of Industrial Works, Ministry of Industry and Industrial Estate Authority of Thailand, which are all controlled by the prime minister directly. In 1978, Thailand partially revised their environmental laws and introduced the Environmental Impact Assessment (EIA) system, which effectively began environmental pollution control. When domestic and foreign direct investments into the manufacturing industry in Thailand increased rapidly from the late 1980s to the 1990s, limitations were found in the environmental pollution control system, and the Thai government enacted the Enhancement and Conservation of National Environmental Quality Act in 1992.

However, the ability to directly control the environmental pollution of factories in industrial areas still remained under the purview of the Department of Industrial Works and Ministry of Industry, which alone had the authority to supervise the companies (Funatsu, 2013). In this same year, 1992, the Factory Act was enacted. It stipulated effluent standards for contaminated waste and hazardous waste in accordance with the scales and industries of the factories (Touma, 2010).

Table 3 shows 23 industrial estates from those listed by Japan External Trade Organization (JETRO) (2010). Approximately 82 percent have already installed water supply facilities and wastewater treatment facilities (19 out of 23), so we can see the trend is towards industrial parks enforcing their own environmental measures. This does not include industrial waste treatment facilities, because they were not included on the list.

Table 3. Environmental measures at industrial estates in Thailand

\begin{tabular}{|c|c|c|c|c|c|}
\hline Area & Industrial Estate & Establishment & Zone & $\begin{array}{c}\text { Water Supply } \\
\text { t/Day }\end{array}$ & $\begin{array}{c}\text { Water Treatment } \\
\text { t/Day }\end{array}$ \\
\hline Bangkok & Bangchan Industrial Estate & 1969 & 1 & 6,500 & \\
\hline Bangkok & Nava Nakorrn Industrial Zone & 1971 & 1 & 120,000 & 50,000 \\
\hline Bangkok & Ladkrabang Industrial Estate & 1976 & 1 & 25,000 & 18,600 \\
\hline North East & Northern Region Industrial Estate & 1983 & 3 & 30,000 & 24,000 \\
\hline South & Southern Industrial Estate (Songkla) & 1984 & 3 & 23,000 & 3,000 \\
\hline Central/West & Rojana Industrial Park (Ayutthaya) & 1988 & 2 & 225,000 & 50,000 \\
\hline Central/West & Hemaraj Saraburi Industrial Land & 1988 & 2 & 785,000 & 10,000 \\
\hline East & Hemaraj Chonburi Industrial Estate & 1988 & 2 & 36,000 & 8,400 \\
\hline East & Hemaraj Eastern Industrial Estate & 1988 & 3 & 60,000 & 12,000 \\
\hline East & Amata Nakon Industrial Estate & 1989 & 2 & 12,600 & \\
\hline East & Asia Industrial Estate & 1989 & 3 & & 28,000 \\
\hline Central/West & Saha Rattana Nakorn Industrial Estate & 1991 & 2 & 10,000 & 8,000 \\
\hline Bangkok & Gemopolis Industrial Estate & 1993 & 1 & & \\
\hline East & IPP Industrial Park & 1994 & 3 & & 1,700 \\
\hline East & 304 Industrial Park & 1994 & 3 & 120,000 & 70,000 \\
\hline East & Amata City Industrial Estate & 1995 & 3 & 7 & \\
\hline East & Eastern Seaboard Industrial Estate & 1995 & 3 & 36,000 & 26,000 \\
\hline East & Hemaraj Rayong Industrial Land & 1995 & 3 & 50,000 & 16,000 \\
\hline North East & Northern Region Industrial Estate (Pichi & 1995 & 3 & & 5,100 \\
\hline Central/West & Khao Yoi Industrial Park & 1996 & 3 & 5,000 & 2,500 \\
\hline East & Hemaraj Eastern Seabord Industrial Esta & 1996 & 3 & 28,000 & 6,000 \\
\hline Central/West & Ratchaburi Industrial Estate & 1998 & 2 & 40,000 & 32,000 \\
\hline North East & Nava Nakorrn Industrial Zone (Nakornra & 2005 & 3 & 50,000 & 6,700 \\
\hline
\end{tabular}

(Source) Prepared by authors from Japan External Trade Organization [JETRO] (2010)

\section{Cambodia}

After decades of civil war and political strife, Cambodia's first general election was held in May, 1993 under the auspices of the United Nations Transitional Authority in Cambodia (UNCTAD), after which Cambodia enjoyed national reconciliation and relative political stability. After the election, the Constitution of the Kingdom of Cambodia was promulgated in September, 1993. Since then, Cambodia has been transformed from a centrally planned economy to a free market economy (Sotharith, 2011). Concurrent with industrial development, FDI also increased. Cambodia enacted a few environmental laws, but no regulations have been enforced (Table 3). 
Table 3. Environmental laws in Cambodia

1996 Law on Environment Protection and Natural Resource Management: LEPNRM

1999 Sub-Decree on Management of Solid Waste

Sub-Decree on Water Pollution Control

Sub-Decree on Implementation of the Environmental Impact Assessment Process

2000 Sub-Decree on Control of Air Pollution and Noise Disturbance

(Source) Prepared by JBIC (2013)

Industrial areas in Cambodia are funded by local, Chinese, and/or Japanese companies as well as through Japanese Official Development Assistance (ODA). Table 4 shows five industrial areas to which foreign companies have already invested in as FDI, and their environmental facilities. The industrial area financed by a Japanese company and ODA are fully equipped with power, water supplies and wastewater treatment facilities while the others, financed by Cambodian and Chinese companies, are not equipped with wastewater treatment facilities. They are not even equipped with water supply facilities. The rent paid for land not equipped with a wastewater treatment facility is around USD $30 / \mathrm{m}^{2}, \mathrm{much}$ less than those fully equipped, at around USD $60 / \mathrm{m}^{2}$. While Cambodian environmental laws are insufficient, those industrial areas funded by Japanese ODA or Japanese companies enforce environmental measures by themselves. It is likely that factories are attracted to cheaper and subsequently, lesser-equipped land, and that this trend causes pollution.

Table 4. Environmental measures at industrial areas in Cambodia

\begin{tabular}{|c|c|c|c|c|c|}
\hline Industrial Area & Phnom Penh & Sihanoukville Port & Sihanoukville & Koh Kong & Poipet \\
\hline Location & Phnom Penh City & $\begin{array}{l}\text { 230km } \\
\text { (Phnom Penh) }\end{array}$ & $\begin{array}{l}\text { 210km } \\
\text { (Phnom Penh) }\end{array}$ & Thai Border & Thai Border \\
\hline Establishment & 2006 & 2009 & 2006 & 2006 & 2005 \\
\hline Fund & $\begin{array}{l}\text { Japanese, } \\
\text { Cambodian }\end{array}$ & $\begin{array}{l}\text { Japanese } \\
\text { (ODA) }\end{array}$ & Chinese & Cambodian & Cambodian \\
\hline Scale & 360 ha & 70 ha & $11.13 \mathrm{~km} 2$ & 335 ha & 385 ha \\
\hline Water Supply & $\begin{array}{l}\text { Water Purification } \\
\text { Facility }\end{array}$ & Underground Water & Nil & $\begin{array}{l}\text { Water Supply } \\
\text { Facility }\end{array}$ & $\begin{array}{l}\text { Water Supply } \\
\text { Facility }\end{array}$ \\
\hline Water Treatment & Central Treatment & Central Treatment & Nil & Nil & Nil \\
\hline Rent & USD $55 / \mathrm{m} 2$ & USD $65 / \mathrm{m} 2$ & USD $28 / \mathrm{m} 2$ & USD $40 / \mathrm{m} 2$ & USD33/m2 \\
\hline
\end{tabular}

(Source) Prepared by JBIC (2013)

\section{Myanmar}

After a long period of political turmoil, Myanmar gave up their military government after about 50 years and changed from a blocked economy to an open economy in 2011. While many MNCs are seeking opportunities to invest, the governmental system for a free market has not been established and little FDI has taken place. For example, an industrial area is being developed near the Thai-Myanmar border, but the Myanmar government intends to introduce only labor intensive local SMEs (small and medium-sized enterprises), which do not require heavy machinery partly because of the government's concern to invite foreigners into a politically-sensitive border area. (Kida \& Fujikura, 2015). However, FDI will likely be accelerated as the economy of the region becomes more integrated.

The government of Myanmar enacted the Environmental Conservation Law in 2012, but no law stipulating regulations have been developed yet. The existing industrial areas were developed by the former military government, and no environmental measures are currently being enforced. While new industrial areas are being established, no effective pollution control laws have been put in place. Table 5 shows five industrial areas in Myanmar, which were invested in by Kayin state, the former military government, or consortium of Japanese and Burmese companies. This sequence of events is similar to what is currently taking place in Cambodia. Industrial areas financed by Japanese companies are fully equipped with power, water supplies and wastewater treatment facilities, while the industrial areas financed by the government of Burma, Kayin state and the former military government of Burma are not equipped with wastewater treatment facilities. The rent paid for land not equipped with wastewater treatment facilities is around USD 40/m2, much less than that of land which is fully equipped at around USD 58/m2. Although there is one exception to this price 
discrepancy, we can say that investors are attracted to cheaper land, which is subsequently lesser-equipped, and that this trend causes pollution.

Table 5. Environmental measures at industrial areas in Myanmar

\begin{tabular}{llllll} 
Industrial Area & Mingaladon & Myawaddy & Dagon Seikkan & South Dagon & Hlaing Thar Yar \\
\hline Location & Yangon City & Thai border & Near Yangon & Near Yangon & Near Yangon \\
\hline Establishment & 1996 & 2014 & 1997 & 1996 & 1995 \\
\hline Fund & $\begin{array}{l}\text { Japanese } \\
\text { Myanmar }\end{array}$ & Kayin state & $\begin{array}{l}\text { Ministry of } \\
\text { Industry }\end{array}$ & $\begin{array}{l}\text { Ministry of } \\
\text { Industry }\end{array}$ & $\begin{array}{l}\text { Ministry of } \\
\text { Industry }\end{array}$ \\
\hline Scale & 89.8 ha & 50 ha & 489 ha & 86 ha & 567 ha \\
\hline Water Supply & Underground & Underground & Underground & Underground & Underground \\
& Water & Water & Water & Water & Water \\
\hline Water Treatment & Central Treatment & Nil & Nil & Nil & Nil \\
\hline Rent & USD 58/m2 & & USD 36/m2 & USD 41/m2 & USD 67/m2
\end{tabular}

(Source) Prepared by JETRO (2013)

\section{Discussion}

The Japanese industrial areas are equipped with water treatment facilities so as not to discharge environmental pollution in Cambodia and Myanmar. However, the proportion of Japanese industrial areas is $8 \%$ in Cambodia and only $2 \%$ in Myanmar (Table 6). This means that the potential to generate environmental pollution is high, because most industrial areas are populated with industrial sites which are likely not equipped with water treatment facilities.

Table 6. Industrial areas developed with Japanese involvement

\begin{tabular}{lcccc} 
Country & Japanese & $(\%)$ & Others & $(\%)$ \\
\hline Cambodia & 2 & 8 & 24 & 92 \\
\hline Myanmar & 1 & 2 & 50 & 98
\end{tabular}

(Source) Prepared by authors

Figure 4 shows a flowchart of options that exist when choosing land in industrial areas in Cambodia and Myanmar, with relation to water treatment facilities. For example, when investors select land to build factories, they perform a feasibility study which compares costs and sales. These costs include initial costs, such as construction costs, and operating costs such as salaries, taxes and rental fees ${ }^{5}$ for land, etc. If investors decide to pay a high rental fee, they can usually build in industrial areas equipped with water treatment facilities. This results in controlling pollution levels within the industrial areas (Case 1). However, if they pay a low rental fee, they cannot control the pollution within the industrial area. Therefore, we can see that an environmental consciousness is necessary to control pollution in these industrial areas. When investors have environmental consciousness or a respect for local environmental law, they will control the pollution at their site, such as the example of the Japanese company in India (Case 2). In industrial areas in Cambodia and Myanmar, investors need to pay higher initial costs to minimize their pollution, because of the premium on land with water treatment facilities. However, investors with no environmental consciousness do not make these considerations as current environmental regulations are not enforced (Case 3). This scenario creates the potential to generate large amounts of pollution. If investors intentionally choose Case 3 , their industrial factories and the surrounding areas will likely be at risk of pollution.

5 The laws in Cambodia and Myanmar do not allow investors to buy land. 


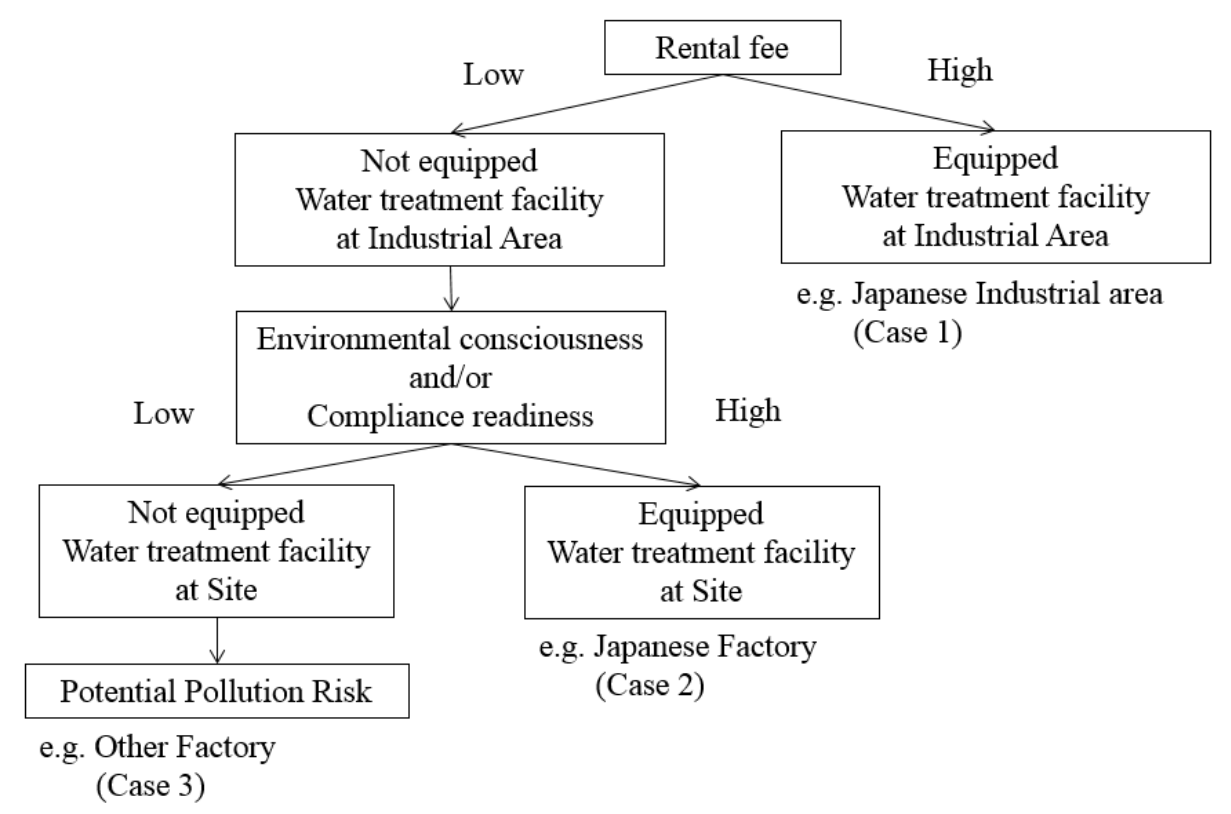

Figure 4. Flowchart of options regarding water treatment facilities in industrial areas in Cambodia and Myanmar (Source) Prepared by authors

FDIs from developed countries, when given to manufacturing industries located in developing countries, may cause environmental problems, as has happened in Mexico. While the environmental regulations of the investing countries are usually well established and enforced, the regulations of the recipient countries are often insufficient. If companies operating in lesser-developed countries voluntarily set adequate standards and meet them in the same way as in their mother countries, pollution problems may be prevented. One such example is Japanese companies operating in Indian industrial areas. However, such behavior cannot always be expected. Without proper enforcement of environmental regulation, pollution would likely occur as the result of FDI.

Thai MNCs have already started to move their factories producing final products to their neighbor countries, Cambodia and Myanmar. While Thailand established environmental policy and its implementation is fairly acceptable, their neighboring countries have not yet fully enforced environmental regulations. The fragmentation just started, and most of the factories are textile and assembly industries, few of whose environmental impact are significant. However, more production processes with significant environmental impact, such as heavy industries or chemical industries, will likely move to the areas as economic integration and fragmentation progress.

The Mexican government concentrated on unskilled labor work for import-substitution for about 20 years. When Mexico started to promote export-orientation in Maquiladora areas in the 1980s, the pollution problems became serious and local residents suffered from pollution-related diseases. However, NAAEC was enacted with economic integration of NAFTA. This agreement was proposed by the US government as a response to the concern of NGOs that NAFTA, without proper environmental management, would worsen Mexican pollution problems. NAAEC forbids alleviating environmental regulation to attract FDIs. Mexican environmental problems were mitigated by economic integration partly because of the concern of a developed country, the United States (Figure 5).

The Hypothesis of Environmental Kuznets Curve (EKC) states that while environmental degradation sharply increases as the economy develops, further increases in per capita income will induce environmental improvement (Gallagher, 2004). EKC theorizes that there is a peak of environmental degradation. Recent studies estimated the peak will be surpassed when the GDP per capita exceeds the range from USD 14,730 to 35,000. At the same time, the hypothesis also indicates that environmental degradation could occur for decades before turning around, or not at all (Gallagher, 2004). Pollution levels in the Maquiladora regions of Mexico indicate that Mexico has already passed the EKC peak (Figure 5). 


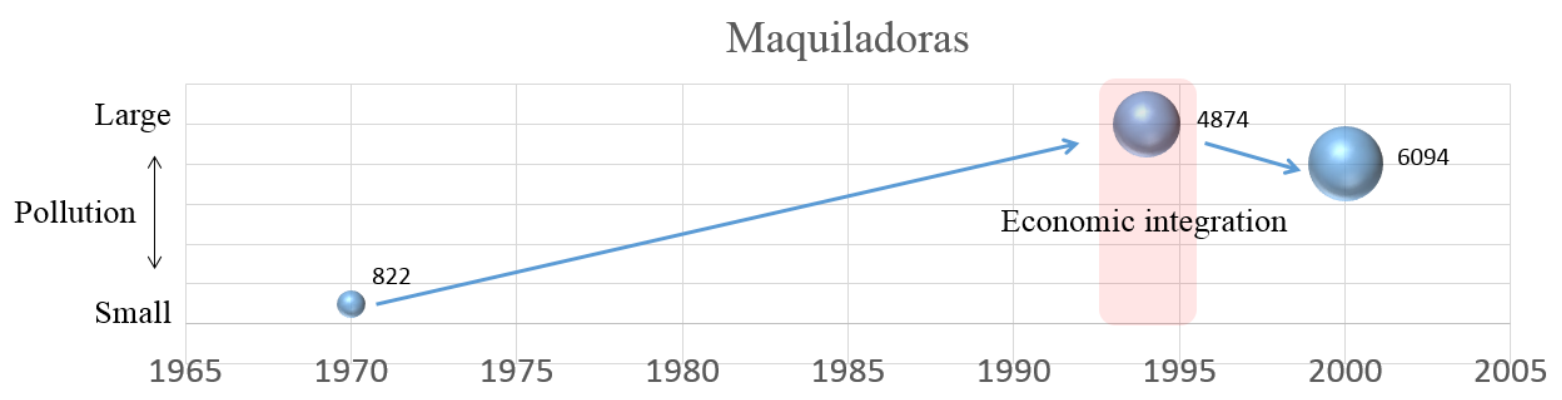

Figure 5. Economic development and pollution levels in the Maquiladora regions

(Source) Prepared by authors

ASEAN seems to be following a similar pattern of economic integration as NAFTA. However, the stages of economic development are different from that of NAFTA. When Mexico joined NAFTA, it has already industrialized and become a semi-developed country. On the other hand, Cambodia began to have a market economy under import-substitution in 1993. Myanmar transformed from a military regime to a democratic one in 2011 and ran its economy under import-substitution. After the economic integration of AFTA, it also will promote export-orientation with import-substitution. The economic development of both Cambodia and Myanmar are far behind from that of Mexico during the 1990s, and the industrialization of the two countries has not yet started (Figure 6). Rapid economic integration and FDIs might pose significant adverse environmental impacts in both countries as seen in Mexico during the 1990s.

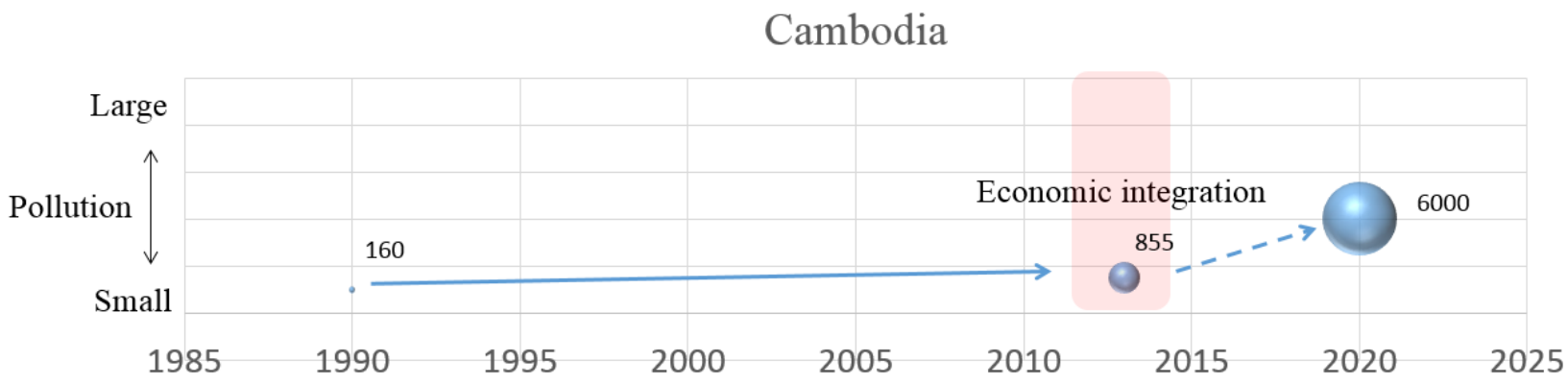

Figure 6. Economic development and possible pollution levels in Cambodia

(Source) Prepared by authors

If the EKC hypothesis is valid for Cambodia and Myanmar, it will likely take decades for them to reach "peak pollution". The AEC Blueprint does not address environmental management on their agenda. It is likely that similar problems will occur as those that transpired in Mexico. However, taking a lesson from NAFTA, a possible measure can be suggested: supplemental environmental agreements like the NAAEC of NAFTA would aid this transition. Under the AEC agreement, Thailand could play a role similar to the US's in NAFTA. When NAFTA was concluded, civil society and NGOs expressed concern and encouraged the governments to conclude NAAEC. The lessons of NAFTA and the NAAEC would be applicable to the case of the AEC since local NGOs in the region are becoming more environmentally aware. Developed countries such as Japan, US, EU member countries and international organizations may be able to support environmental initiatives in the region.

\section{Acknowledgement}

The authors appreciated Mr. Ajit Singh for his thoughtful and helpful comments. This work was partly supported by Hosei Graduate School Research Grant for Doctoral Studies.

\section{Reference}

Association of Southeast Asian Nations [ASEAN]. (2008) ASEAN Economic Community Blueprint, ASEAN.

Association of Southeast Asian Nations [ASEAN]. (2009) ASEAN Socio-Cultural Community Blueprint, ASEAN.

Bowen, M. M., Kontuly T., \& Henpner, G. F. (1995). Environmental Auditing - Estimating Maquiladora Hazardous Waste Generation on the U.S./Mexico Border, Environmental Management, 9(2), 281-296.

Funatsu, T., (2013). Pollution and Environmental Administration in Thailand in the 2000s: Analysis of the Map Ta Put 
Environmental Lawsuit in Rayong, Terao, T., (Ed.), The Formation of Environmental Policies in the Process of Economic Development: From the Viewpoint of "Development and the Environment", the Institute of Development economies, JETRO.

Gallagher, K. P. (2004). Free Trade and the Environment: Mexico, NAFTA, and Beyond, Stanford Law and Politics.

Ishido, H., \& Ito, K. (2014). Zaiboeki, Ishiguro, I., (Ed), The Economics of East Asian Integration, Nippon Hyoron Sha.

Ishikawa, K. (2013). ASEAN kyodotai wa dekirunoka, Ishikawa, K., Shimizu, K., \& Sukegawa, N., (Eds.). ASEAN Keizaikyodotai to nihon - kyodaitougouaijyou no tanjo-, Bunshinsya.

Japan Bank for International Cooperation [JBIC]. (2013). Kanbojia no Toushikankyo, JBIC.

Japan External Trade Organization [JETRO]. (2010) Taikoku Kogyodanchichosa hokokusyo, JETRO.

Japan External Trade Organization [JETRO]. (2013). Data collection of Industrial Zone in Myanmar, JETRO.

Kasuga, N. (2014). ASEAN shifutogasusumu nikkeikigyou - toigoukasuru mekonchiiki-, Bunshinsya.

Kida, T., \& Fujikura, R. (2015). A Chance in Myanmar Induced by the Minimum Wage Policy in Thailand - A Case Study of Myawaddy Industrial Area-, International Journal of Social Science Study, 3(1), 38-46.

Kin, K. (1999). Jiyuboeki to kankyohogo - NAFTA wa choseino moderuni naruka, Fukosya.

Perry, D. M., Sanchez, R., Glaze, W. H., \& Mazari, M. (1990). Binational Management of Hazardous Waste: The Maquiladora Industry at the US-Mexico Border, Environmental Management, 14(4), 441-450.

Rajaram, T., \& Das, A. (2008). Water pollution by industrial effluents in India: Discharge scenarios and case for participatory ecosystem specific local regulation, Future, 40, 56-69.

Sanchez, R. A. (1990). Health and Environmental Risks of the Maquiladora in Mexicali, Natural Resource Journal, 1990 Winter, 163-186.

Shimizu, K. (2013). Sekaikeiai to ASEAN no keizaitougou - ASEAN keizaikyoudoutai no tanjo -, shikawa, K., Shimizu, K., \& Sukegawa, N., (Eds.). ASEAN Keizaikyodotai to nihon - kyodaitougouaijyou no tanjo-, Bunshinsya.

Sotharith, C. (2011). Industrial Development Policy and Intermediate Goods Trade in Cambodia, Intermediate Goods Trade in East Asia: Economic Deeping through FTAs/EPAs. Bangkok Research Center IDE-JETRO.

Tajima, Y. (2006). Gurobarizumu To Rijonarizumu No Soukatsu-Mekkishiko No Kaihatsu Senryaku-. Kouyou Syobou.

Taniura, T. (2000). The industrial development in Mexico: Location, Policy and Industrial Organization, Institute of Developing Economies.

Touma, M. (2010), Maputaputto kogyodanchisyuuhen no sangyouhattenn to kankyouosen ni tuite, Shoho, 34-39, Japanese Chamber of Commerce, Bangkok.

Tsujita, Y. (2005). Development of Controlling Industrial Pollution and Its Problems in India: Reexamining the Role of the Judiciary, Terao, T., \& Otsuka, K., (Eds.), Environmental Policy in a Changing Asia: Industrialization, Democratization, and Globalization, Institute of Developing Economies

\section{$(\mathrm{cc}) \mathrm{BY}$}

This work is licensed under a Creative Commons Attribution 3.0 License. 